\title{
Immunosuppressive effect of cyclosporin A on resistance to systemic infection with Candida albicans
}

\author{
A. VECCHIARELLI, E. CENCI, P. MARCONI, R. ROSSI*, C. RICCARDI† \\ and F. BISTONIF
}

\begin{abstract}
Department of Experimental Medicine and Biochemical Sciences, Microbiology and + Pharmacology Sections, and "Institute of General Pathology, University of Perugia, Perugia, Italy
\end{abstract}

\begin{abstract}
Summary. We studied the influence of cyclosporin-A (Cy-A) on resistance of mice to systemic infection with Candida albicans. Cy-A clearly inhibited resistance to $C$. albicans. The effect was dose-dependent and time and route of administration of the drug were important. This immunodepressive effect was due, at least in part, to an impairment of polymorphonuclear leucocyte (PMNL) candidacidal activity, as demonstrated in vitro by a reduction of phagocytic and cytotoxic activity and in vivo by protection when PMNL from untreated mice were transferred into cyclophosphamide-treated hosts challenged with $C$. albicans. The decreased activity of PMNL could be partly restored by adoptive transfer of normal T-lymphocytes into Cy-Atreated mice, as well as by exposure of PMNL to gamma-interferon (IFN- $\gamma$ ) in vitro.
\end{abstract}

\section{Introduction}

Cell-mediated immunity is a crucial factor in host defence against systemic infection with many fungi, including Candida albicans (Baccarini et al., 1983a). The results of several experimental studies indicate that phagocytic cells, acting through nonspecific mechanisms, are important in resistance to systemic $C$. albicans infection and are capable of phagocytosing and killing $C$. albicans in vitro (Lehrer, 1972; Sasada and Johnston, 1980; Bistoni et al., 1982, 1986; Baccarini et al., 1983b). In particular, previous observations suggest an important role for polymorphonuclear leucocytes (PMNL) and macrophages in resistance to $C$. albicans infections in vivo (Lehrer, 1969; Ruthe et al., 1978; Hurtrel et al., 1980; Baccarini et al., 1985). The killing activity in vitro is not affected by treatment with anti-Thy 1 serum or anti-asialo GM-1 serum plus complement (Baccarini et al., $1983 a$ ) and phagocytic cells isolated from nude mice are also actively candidacidal (Baccarini et al., 1983b).

Immunomodulating agents have been employed previously to evaluate the possible role of different components of the immune system in experimental infections. In the case of experimental C. albicans

Received 10 Feb. 1988; revised version accepted 11 Oct. 1988 ‡Correspondence should be addressed to Professor F. Bistoni, Department of Experimental Medicine and Biochemical Sciences, University of Perugia, Via del Giochetto, Perugia, Italy. infection, both immunosuppressive and immunostimulating drugs have been studied (Moser and Domer, 1980; Baccarini et al., 1983a; Bistoni et al., $1983,1984,1985)$. We have examined the possible effect of cyclosporin A (Cy-A) on resistance to $C$. albicans challenge in mice. This drug has been reported to be a powerful immunosuppressant in all species tested; in man, it acts principally on $\mathrm{T}$ cells, and sometimes also on B cells, and has remarkably low myelotoxicity (Borel et al., 1976; Larsson, 1980; Wiesinger and Borel, 1980; Britton and Palacios, 1982; Kaufman et al., 1984; Hess and Colombani, 1986).

\section{Materials and methods}

\section{Mice}

Inbred BALB/c $\mathrm{Cr}\left(\mathrm{H}^{d}\right)$ and hybrid (BALB/c $\mathrm{Cr} \times$ DBA/2 Cr) F1 (CD2F1 : H2 $\left.2^{\mathrm{d}} / \mathrm{H} 2^{\mathrm{d}}\right)$ mice, 2-4 months old, of both sexes, were obtained from Charles River Breeding Laboratories Inc., Calco, Milan, Italy.

\section{Drugs}

Cyclosporin A (Cy-A) was kindly provided as a gift by Sandoz Ltd, Basel, Switzerland. For administration in vivo, the drug was dissolved in Miglyol 812 (Dynamit Nobel, Witter, FRG), as described by Bout et al. (1986), to the desired concentration and injected by the intraperitoneal (i.p.), subcutaneous (s.c.) or intramuscular (i.m.) 
route in a volume of $0.1 \mathrm{ml} / 10 \mathrm{~g}$ of body weight. Control mice received Miglyol 812 alone. Cyclophosphamide (CY, Endoxan; Asta Werke, FRG) was dissolved in sterile $\mathrm{NaCl} 0.85 \%$ immediately before use and injected i.p. at a dose of $150 \mathrm{mg} / \mathrm{kg}$ in a volume of $0.1 \mathrm{ml} / 10 \mathrm{~g}$ of body weight.

\section{Candida albicans}

C. albicans, laboratory strain CA-6, was isolated from a clinical specimen (Marconi et al., 1976). It was grown at $28^{\circ} \mathrm{C}$ with mild agitation in low-glucose Winge medium (Mattia et al., 1982) containing glucose $0.2 \% \mathrm{w} / \mathrm{v}$ and yeast extract (BBL Microbiology Systems, Cockeysville, MD, USA) $0.3 \% \mathrm{w} / \mathrm{v}$ until the stationary phase of growth was reached at about $24 \mathrm{~h}$. Under these conditions, cultures yielded c. $3 \times 10^{8}$ cells $/ \mathrm{ml}$, and the organism grew as an essentially pure yeast-phase population. Cells were harvested from the $24-\mathrm{h}$ culture by low-speed centrifugation $(600 \mathrm{~g})$, washed twice in saline and diluted to the desired density.

\section{Leucocyte counts}

Mice were bled from the retro-orbital sinus (10 mice were used for each determination). Cell counts were made by diluting anticoagulated blood 1 in 20 in Türk solution and counting the cells in a counting chamber. Differential cell counts were made on blood smears stained by the May-Grünwald-Giemsa method by counting 200 leucocytes on each slide. Standard errors never exceeded $10 \%$ of the mean and, therefore, have been omitted from the results.

\section{Preparation of phagocytic cells}

Peritoneal PMNL were obtained from the peritoneal cavities of mice $18 \mathrm{~h}$ after i.p. injection of $1 \mathrm{ml}$ of thioglycolate broth $10 \%$. Cells were harvested by peritoneal washing and approximately $85 \%$ of them were identified as PMNL on morphological criteria. When specified, experiments were performed with circulating PMNL separated from peripheral blood by FicollHypaque solution as described by Klock and Bainton (1976).

Spleen cells were harvested by adherence to plastic. Resident or thioglycolate-induced (i.p. injection of broth 4 days earlier) peritoneal cells were harvested as above and suspended $\left(1 \times 10^{7}\right.$ cells $)$ in $10 \mathrm{ml}$ of RPMI 1640 medium (Eurobio Laboratories, Paris) in 93-mm plastic petri dishes (Nunc InterMed, Roskilde, Denmark). After incubation for $2 \mathrm{~h}$ at $37^{\circ} \mathrm{C}$ in an atmosphere of $\mathrm{CO}_{2} 5 \%$ in air, the dishes were washed thoroughly with RPMI 1640 medium to remove the non-adherent cells. The adherent cells were recovered by scraping the dish with a "rubber policeman", and were washed and suspended in RPMI 1640 medium supplemented with fetal calf serum (GIBCO Laboratories, Grand Island, NY, USA) $10 \%$, 25 mM HEPES (N-2-hydroxyetyl-piperazine-N'-2-etha- nesulphonic acid) buffer (Eurobio), and gentamicin sulphate $0.1 \%$ (hereafter referred to as complete RPMI 1640 medium). More than $99 \%$ of the recovered cells had the morphology of macrophages in Giemsa-stained smears and their viability was $85-90 \%$.

\section{Adoptive transfer of lymphocytes}

The non-adherent cells separated by the plastic adherence fractionation method (see above) were passed over a nylon fibre column as described by Julius $e t$ al. (1973). The fraction that was recovered comprised 98$99 \%$ T-lymphocytes, as determined by their morphology in May-Grünwald-Giemsa stained smears and confirmed by immunofluorescence with fluorescein-labelled antiThy 1, 2 antibodies (New England Nuclear). These lymphocytes were injected intravenously (i.v.) into recipient mice $\left(25 \times 10^{6}\right.$ cells/mouse $)$.

\section{Interferon}

Cloned murine gamma-interferon (IFN- $\gamma$ ) was kindly provided by Genentech, Inc. (South San Francisco, CA, USA).

\section{Transfer of PMNL and C. albicans mixtures}

C. albicans cells $\left(1 \times 10^{4}\right)$ were mixed with $20 \times 10^{4}$ PMNL from normal or Cy-A-treated mice and incubated at $37^{\circ} \mathrm{C}$ in air $+\mathrm{CO}_{2} 5 \%$. After contact for $1 \mathrm{~h}$, the $0.5-$ $\mathrm{ml}$ volumes of the mixtures were injected i.v. into CYimmunodepressed mice.

\section{Measurement of phagocytic activity in vitro}

Microscopic examination of phagocytic cell function was performed by mixing equal volumes $(0 \cdot 1 \mathrm{ml})$ of effector cells, the indicator dye methylene blue, and a suspension of heat-inactivated yeast cells in sterile polypropylene tubes (Becton Dickinson) at an effector cell: yeast cell ratio of $1: 10$. Triplicate samples of the mixtures were incubated for different times at $37^{\circ} \mathrm{C}$. Phagocytic cells were separated from non-phagocytosed C. albicans by centrifugation on a fetal bovine serum gradient (Shalaby et al., 1985) and 0.1-ml samples of the harvested phagocytic cells were used to prepare wet mounts for microscopy. The phagocytic activity of effector cells was expressed according to the following formula: percentage phagocytic activity = number of cells containing one or more yeast cells/ 100 cells counted.

\section{In vitro cytotoxicity assays}

${ }^{51} \mathrm{Cr}$ release assay. The candidacidal activity of various effector cell populations was assessed by the technique described by Bistoni et al. (1982). Briefly, PMNL or single-cell suspensions from the spleen were prepared and different numbers of effector cells in $0.1 \mathrm{ml}$ of the suspension were mixed in U-shaped 96-well microtitra- 
tion plates with $0 \cdot 1 \mathrm{ml}$ of a suspension of $5 \times 10^{4}{ }^{51} \mathrm{Cr}$ labelled yeast cells $\left(2 \times 10^{8}\right.$ cells were incubated with $300 \mu \mathrm{Ci}$ of $\mathrm{Na}_{2}{ }^{51} \mathrm{CrO}_{4}$ for $2 \mathrm{~h}$ ). After incubation for $4 \mathrm{~h}$ at $37^{\circ} \mathrm{C}$ in air $+\mathrm{CO}_{2} 5 \%$, the plates were centrifuged at $800 \mathrm{~g}$ for $10 \mathrm{~min}$, and the radioactivity in $0.1 \mathrm{ml}$ of the supernate was measured in a $\gamma$-scintillation counter (Auto Gamma 500 C; Packard Instrument Co., Inc., Downers Grove, IL, USA). The base-line ${ }^{51} \mathrm{Cr}$ release was that of yeast cells incubated alone in complete RPMI 1640 medium; in no case did the release exceed $20 \%$ of the total counts/min (cpm) incorporated by target yeast cells. The experimental results are expressed as the percentage of killing of yeast cells in the experimental group (quadruplicate samples) represented by the ${ }^{51} \mathrm{Cr}$ release (cpm) above the base-line control according to the following formula: specific ${ }^{51} \mathrm{Cr}$ release $(\%)=$

$$
\begin{aligned}
& \text { (cpm experimental group } \\
& {\left[\frac{- \text { cpm spontaneous group) } \times 2}{\text { total cpm }}\right] \times 100}
\end{aligned}
$$

in which total cpm is the radioactivity incorporated by $5 \times 10^{4}$ candida cells.

Inhibition assay by plate counts. Phagocytic cells $(5 \times$ $10^{5}$ in $0 \cdot 1 \mathrm{ml}$ of suspension per well) were mixed in Ushaped 96-well microtitration plates (Greiner Labortechnick, Nürtingen) with $C$. albicans cells $\left(5 \times 10^{4}\right.$ cells in $0.1 \mathrm{ml}$ of suspension/well). After incubation for $4 \mathrm{~h}$ at $37^{\circ} \mathrm{C}$ in air $+\mathrm{CO}_{2} 5 \%$, the plates were shaken vigorously, and serial dilutions in distilled water were made from each well. Cell suspensions were incubated with distilled water until microscopic examination revealed the complete disruption of phagocytes. Triplicate samples from each dilution were spread on Sabouraud glucose agar. The numbers of cfu were counted after incubation for $18 \mathrm{~h}$ at $37^{\circ} \mathrm{C}$. Control cultures were C. albicans cells incubated without phagocytes.

\section{Culture of $C$. albicans from kidneys}

Both kidneys of normal or Cy-A treated mice, challenged i.v. with $5 \times 10^{5} \mathrm{C}$. albicans cells, were removed aseptically and placed together in a tissue homogeniser with $3 \mathrm{ml}$ of sterile $\mathrm{NaCl} 0.85 \%$. The number of $C$. albicans cfu in a specimen was determined by a plate dilution method with culture on Sabouraud glucose agar. The colonies were counted after incubation at $37^{\circ} \mathrm{C}$ for $48 \mathrm{~h}$, and the results were expressed as the number of cfu/ organ.

\section{Statistical analysis}

Differences in survival times were assessed by the Mann-Whitney U test. Differences in the numbers of cfu or the amounts of the specific radiolabel release in the invitro microcytotoxicity assays were assessed by Student's $t$ test. Each experiment was repeated three to five times.

\section{Results}

Effect of $C y$-A treatment on the resistance of mice to systemic challenge with $C$. albicans

We performed experiments to test the influence of $\mathrm{Cy}-\mathrm{A}$ treatment on the resistance of mice to i.v. injection of a lethal dose $\left(5 \times 10^{5}\right.$ cells $)$ of $C$. albicans (fig. 1). Treatment, at different times before challenge and with different doses of $\mathrm{Cy}-\mathrm{A}$, caused a significant reduction of median survival time (MST) in some of the groups compared with untreated controls. In particular, doses of 50,25 , or $12.5 \mathrm{mg} / \mathrm{kg}$, given 1 day before $C$. albicans challenge, or 50 or $25 \mathrm{mg} / \mathrm{kg}$, given 3 days before, reduced the MST. By contrast, none of the four doses of $\mathrm{Cy}-\mathrm{A}$ given 7 days before challenge significantly reduced MST when compared with untreated controls. These data indicate that $\mathrm{Cy}-\mathrm{A}$ induces a rapid and transient depression of the mechanisms responsible for resistance to $C$. albicans challenge in vivo.

We further examined the effect of $\mathrm{Cy}$-A treatment before challenging with different doses of C. albicans (table I). The administration of Cy-A $25 \mathrm{mg} / \mathrm{kg}, 1$ or 3 days before challenge, significantly impaired host resistance to systemic infection following challenge with different doses of $C$. albicans. This suppressive effect was most evident when mice challenged with $5 \times 10^{4} \mathrm{C}$. albicans cells had been pretreated with $\mathrm{Cy}-\mathrm{A} 1$ or 3 days before challenge. In this case the MST was 17 days, while the control mice survived indefinitely ( $>60$ days).

\section{Effect of Cy-A treatment on recovery of $C$. albicans from the kidneys of mice after i.v. challenge}

We have shown previously that the number of $C$. albicans cfu recovered from the kidneys correlates well with the level of resistance of mice to challenge with C. albicans (Bistoni et al., 1984). To examine further the nature of $\mathrm{Cy}-\mathrm{A}$-induced depression of resistance to $C$. albicans infection in vivo, we also compared the recovery of $C$. albicans cfu from the kidneys of untreated animals with those from $\mathrm{Cy}-$ A-treated animals (table II). The counts of cfu from the kidneys of animals treated with Cy-A 1 or 3 days before $C$. albicans challenge were compared with those of untreated animals. Cy-A pretreatment caused a significant increase in the number of $\mathrm{cfu}$ that was evident after $24 \mathrm{~h}$ and was more marked $48 \mathrm{~h}$ after challenge. As expected, Cy-A treatment caused a significant reduction in host resistance as shown by the comparison of MST of the different groups of treated and untreated animals. 


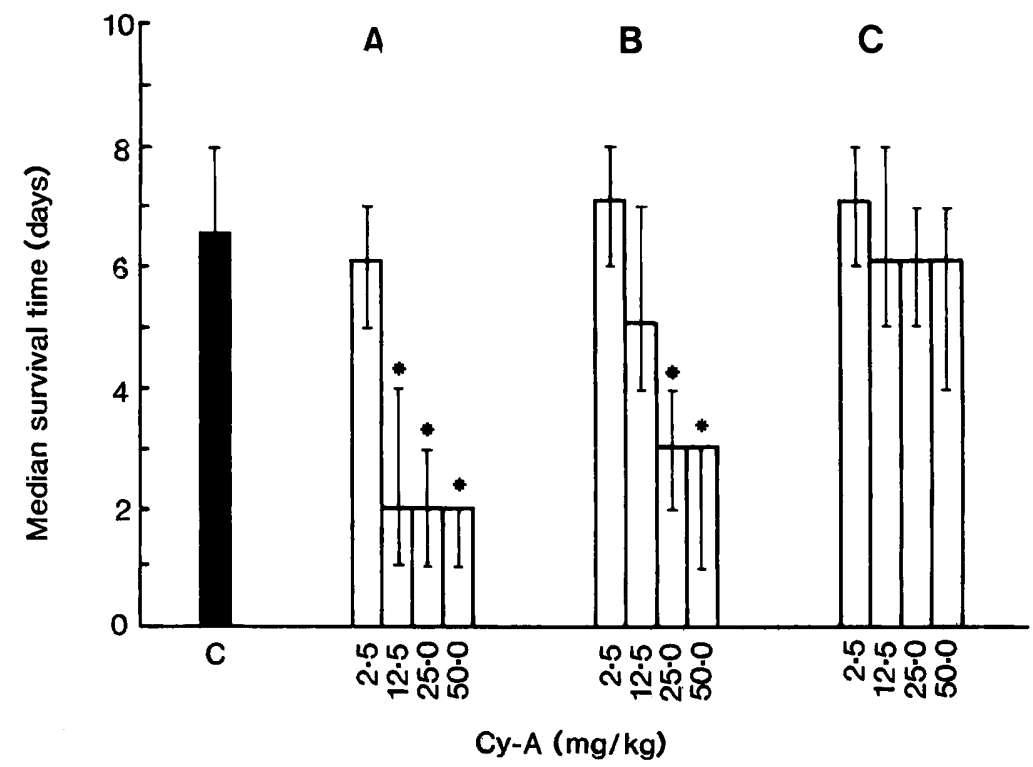

Fig. 1. Effect of dose and time of administration of Cy-A on survival of CD2F1 mice challenged i.v. with $5 \times 10^{5} C$. albicans cells: $\square$, untreated controls; $\square$, mice (10 mice/group) treated with $\mathrm{Cy}-\mathrm{A} 1(\mathbf{A}), 3(\mathbf{B})$ or $7(\mathbf{C})$ days before challenge. Vertical bars represent the survival ranges (days); ${ }^{*} \mathrm{p}<0.01$ (Cy-A treated mice versus untreated).

\section{Effect of Cy-A treatment on PMNL-mediated cytotoxic activity against $C$. albicans}

We performed experiments to determine the number and candidacidal activity of PMNL in mice treated with $\mathrm{Cy}-\mathrm{A}$ (table III). Treatment with Cy-A $(25 \mathrm{mg} / \mathrm{kg}$, i.p.), by any administration schedule, did not significantly alter the number of peripheral lymphocytes nor the number of mono- cytes and PMNL. Therefore, we examined peripheral and thioglycolate-induced PMNL for their cytotoxicity against ${ }^{51} \mathrm{Cr}$-labelled $C$. albicans in vitro as well as for their ability to inhibit $C$. albicans growth in a cfu assay, as previously described (Bistoni et al., 1982). A significant reduction of cytotoxic activity and reduction of inhibition of $C$. albicans cfu recovery by peripheral and thioglycolate-induced PMNL was evident in the groups of

Table I. Survival of normal or Cy-A-treated CD2F1 mice after systemic challenge with $C$. albicans

\begin{tabular}{c|cccc}
\hline $\begin{array}{c}\text { Treatment with Cy-A* } \\
\text { before challenge } \\
\text { (days) }\end{array}$ & $\begin{array}{c}\text { Number of } C \\
\text { albicans }\end{array}$ & MST $\dagger$ & $\begin{array}{c}\text { Number of mice } \\
\text { dead (10 per group) }\end{array}$ & $\begin{array}{c}\text { Survival range (days) } \\
\text { of fatal cases }\end{array}$ \\
\hline No treatment & $5 \times 10^{4}$ & 60 & 0 & $\ldots$ \\
7 & $5 \times 10^{4}$ & 60 & 3 & $11-19$ \\
3 & $5 \times 10^{4}$ & $17 \ddagger$ & 7 & $9-18$ \\
1 & $5 \times 10^{4}$ & $17 \ddagger$ & 9 & $10-18$ \\
No treatment & $10^{5}$ & 12 & 10 & $9-14$ \\
7 & $10^{5}$ & 10 & 10 & $8-14$ \\
3 & $10^{5}$ & $8 \ddagger$ & 10 & $7-9$ \\
1 & $10^{5}$ & $7 \ddagger$ & 10 & $6-9$ \\
No treatment & $5 \times 10^{5}$ & 8 & 10 & $6-9$ \\
7 & $5 \times 10^{5}$ & 8 & 10 & $3-5$ \\
3 & $5 \times 10^{5}$ & $3 \ddagger$ & 10 & $4-5$ \\
1 & $5 \times 10^{5}$ & $4 \ddagger$ & 10 & \\
\hline
\end{tabular}

*, Cy-A $25 \mathrm{mg} / \mathrm{kg}$ as a single i.p. injection.

$\dagger$, MST, median survival time (days).

$\ddagger \mathrm{p}<0.01$ (Cy-A-treated mice versus controls). 
Table II. Survival, and recovery of C. albicans from kidneys, of normal or Cy-A-treated CD2F1 mice after systemic challenge

\begin{tabular}{c|cccccc}
\hline & \multicolumn{4}{|c}{} & \multicolumn{4}{c}{ C. albicans $\begin{array}{c}\text { (cfu } \times 10^{3} \text { ) recovered from } \\
\text { kidneys }\end{array}$} \\
$\begin{array}{c}\text { Treatment with } \\
\begin{array}{c}\text { Cy-A* before } \\
\text { challenge (days) }\end{array}\end{array}$ & MST & $\begin{array}{c}\text { Number of mice } \\
\text { dead (10 per group) }\end{array}$ & $\begin{array}{c}\text { Survival range (days) } \\
\text { of fatal cases }\end{array}$ & $8 \mathrm{~h} \dagger$ & $24 \mathrm{~h} \dagger$ & $48 \mathrm{~h} \dagger$ \\
\hline No treatment & 8 & 10 & $7-8$ & 0.9 & $5 \cdot 7$ & $167 \cdot 3$ \\
3 & $4 \ddagger$ & 10 & $3-5$ & $1 \cdot 2$ & $85 \cdot 5 \ddagger$ & $306 \cdot 0 \ddagger$ \\
1 & $3 \ddagger$ & 10 & $3-5$ & $1 \cdot 0$ & $268 \cdot 1 \ddagger$ & $2394 \cdot 9 \ddagger$ \\
\hline
\end{tabular}

*, Cy-A $25 \mathrm{mg} / \mathrm{kg}$ as a single i.p. injection before challenge with $5 \times 10^{5} \mathrm{C}$. albicans cells $/ \mathrm{mouse}$.

† Time after challenge; data are means of triplicate samples; standard errors, usually $<15 \%$ of the value, have been omitted.

$\ddagger \mathrm{p}<0.01$ (Cy-A-treated mice versus controls).

Table III. Effect of Cy-A administration on the number of peripheral leucocytes and the candidacidal activity of peripheral and thioglycolate-induced PMNL of CD2F1 mice in vitro

\begin{tabular}{|c|c|c|c|c|c|c|c|c|c|c|}
\hline \multirow{4}{*}{$\begin{array}{l}\text { Treatment } \\
\text { with Cy-A* } \\
\text { before chal- } \\
\text { lenge (days) }\end{array}$} & & & & & \multicolumn{6}{|c|}{ Candidacidal activity of } \\
\hline & & & & & & eriphera & 1 PMNL & thiogl & colate-in & duced PMNL \\
\hline & \multicolumn{4}{|c|}{ Peripheral leucocyte counts } & \multicolumn{2}{|c|}{$\begin{array}{l}\text { Percentage }{ }^{51} \mathrm{Cr} \\
\text { specific release } \\
\text { at ratio } \dagger\end{array}$} & \multirow{2}{*}{$\begin{array}{c}\text { Percentage } \\
\text { cfu inhibition } \\
\text { (SE) at ratio } \dagger \\
10: 1\end{array}$} & \multicolumn{2}{|c|}{$\begin{array}{l}\text { Percentage }{ }^{51} \mathrm{Cr} \\
\text { specific release } \\
\text { at ratio }\end{array}$} & \multirow{2}{*}{$\begin{array}{c}\text { Percentage } \\
\text { cfu inhibition } \\
\text { (SE) at ratio† } \\
10: 1\end{array}$} \\
\hline & $\begin{array}{l}\text { Total } \\
\text { WBC }\end{array}$ & $\begin{array}{l}\text { lympho- } \\
\text { cytes }\end{array}$ & PMNL & $\begin{array}{l}\text { mono- } \\
\text { cytes }\end{array}$ & $10: 1$ & $2 \cdot 5: 1$ & & $10: 1$ & $2 \cdot 5: 1$ & \\
\hline No treatn & 362 & 2150 & 1261 & 21 & 30 & 21 & 80.0 & 35 & 29 . & $78 \cdot 5 \quad(5 \cdot 3)$ \\
\hline 7 & 3613 & 1889 & 1473 & 25 & 28 . & 23 & $73.2 \quad(7.3$ & 29.5 & $23 \cdot 1$ & $71.9 \quad(2.1)$ \\
\hline 3 & 3310 & 2002 & 1104 & 204 & $16.9 \ddagger$ & $12 \cdot 6 \ddagger$ & $36 \cdot 4 \ddagger(4 \cdot 0)$ & $19 \cdot 3 \ddagger$ & $14 \cdot 8 \ddagger$ & $40 \cdot 3 \ddagger(3 \cdot 5)$ \\
\hline 1 & 3059 & 1660 & 1214 & 185 & $17 \cdot 3 \ddagger$ & $10 \cdot 1 \ddagger$ & $33 \cdot 5 \ddagger(6 \cdot 3)$ & $15 \cdot 6 \ddagger$ & $12 \cdot 3 \ddagger$ & $28 \cdot 6 \ddagger(3 \cdot 1)$ \\
\hline
\end{tabular}

* Cy-A $25 \mathrm{mg} / \mathrm{kg}$ as a single i.p. injection before the in-vitro assay and peripheral leucocyte counts.

$\dagger$ Ratios of effector to target cells; data are the means of quadruplicate samples; standard errors of ${ }^{51} \mathrm{Cr}$-release assay, usually $<1.5 \%$, have been omitted.

$\ddagger \mathrm{p}<0.01$ (Cy-A-treated mice versus controls).

animals treated 1 or 3 days before with Cy-A $25 \mathrm{mg} /$ $\mathrm{kg}$. We also evaluated the phagocytic activity of PMNL from $\mathrm{Cy}-\mathrm{A}$ treated mice. As shown in fig. 2, PMNL from animals treated with $\mathrm{Cy}-\mathrm{A} 3$ days before the PMNL were harvested showed significantly reduced phagocytic activity. Our data suggest that $\mathrm{Cy}-\mathrm{A}$ treatment did not alter the number of circulating PMNL but significantly reduced their ability to phagocytose and inhibit the growth of $C$. albicans.

On the basis of these observations, we investigated the possibility that the candidacidal activity of resident, thioglycolate-induced macrophages and splenic macrophages could be affected also. The results are shown in table IV. The candidacidal activity of these different macrophage populations was not affected by $\mathrm{Cy}-\mathrm{A}$ treatment, suggesting that the reduction of resistance to $C$. albicans challenge in vivo after $\mathrm{Cy}-\mathrm{A}$ treatment was due to the effects on candidacidal activity of PMNL but not of macrophages.

\section{Protective ability of $P M N L$ from $C y$ - $A$-treated mice in transfer experiments}

We reported previously that it is possible to increase significantly the MST of immunodepressed mice infected with $C$. albicans by adoptive transfer of PMNL (Baccarini et al., 1985). To document further the effect of treatment with Cy-A on PMNL activity, we performed transfer experiments with PMNL from untreated or Cy-A-treated animals 


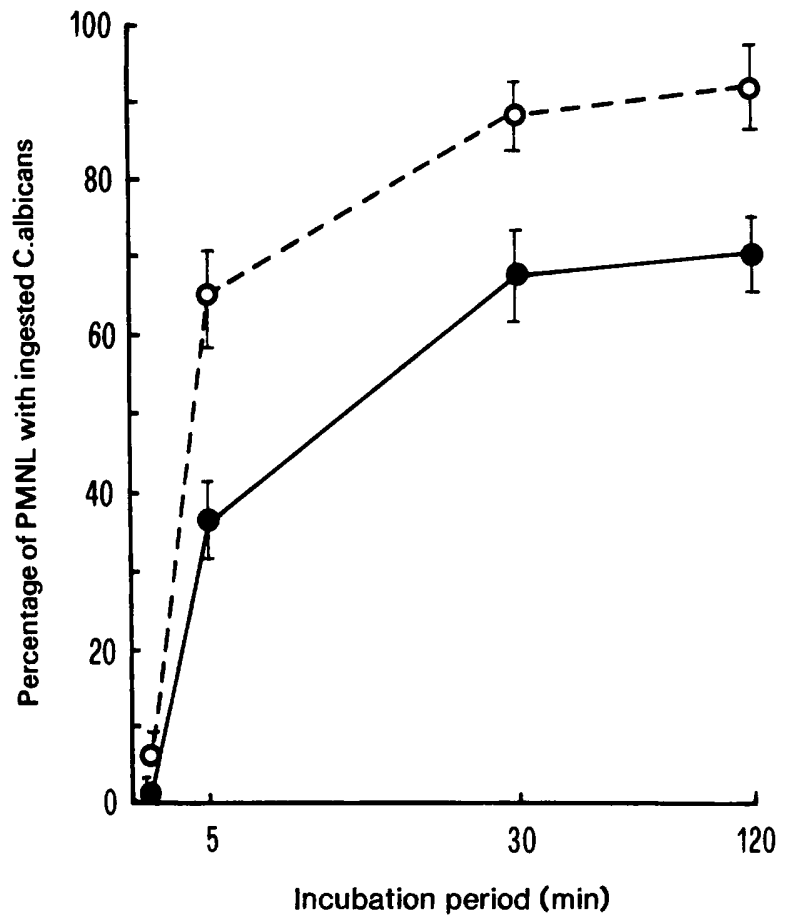

Fig. 2. Effect of $\mathrm{Cy}-\mathrm{A}$ administration on in-vitro phagocytic efficiency of PMNL incubated with inactivated $C$. albicans. $\mathrm{Cy}-\mathrm{A}(25 \mathrm{mg} / \mathrm{kg})$ was given as a single i.p. injection 3 days before collection of PMNL for the assay. PMNL from normal $(\mathrm{O}-\mathrm{O})$ or $\mathrm{Cy}$-A-treated (-O) $\mathrm{CD} 2 \mathrm{~F} 1$ mice were incubated in vitro with inactivated $C$. albicans at a ratio of $1: 10$.

The results were obtained by counting 100 PMNL for each incubation period; $\mathrm{p}<0.01$ for phagocytosis by PMNL from $\mathrm{Cy}-\mathrm{A}$ treated mice versus controls.

(table V). The i.v. injection of PMNL from untreated donors into CY-treated recipients significantly increased the MST of animals challenged with $C$. albicans (group 2) compared with control animals (group 1). In contrast, the adoptive transfer of PMNL from Cy-A-treated $(25 \mathrm{mg} / \mathrm{kg} 3$ and 1 day before the assay) donors did not result in any significant protection against $C$. albicans challenge (groups 3 and 4). These results demonstrate that PMNL of Cy-A-treated animals, unlike PMNL from normal donors, are not able to protect immunodepressed mice.

\section{Effect of different routes of $C y-A$ administration on PMNL activity}

We also tested the possible effect of Cy-A administration by different routes. $\mathrm{Cy}-\mathrm{A}$ doses were injected i.p., s.c. or i.m. and we evaluated both resistance to $C$. albicans challenge in vivo and cytotoxic activity of PMNL in vitro. As shown in
Table IV. Effect of Cy-A administration on in-vitro candidacidal activity of peritoneal resident or thioglycolate-induced macrophages and plastic-adherent spleen cells of CD2F1 mice

\begin{tabular}{|c|c|c|c|}
\hline \multirow[b]{2}{*}{$\begin{array}{l}\text { Treatment with } \\
\text { Cy-A* before } \\
\text { challenge (days) }\end{array}$} & \multicolumn{3}{|c|}{ Percentage cfu inhibition (SE) with $\uparrow$} \\
\hline & $\begin{array}{c}\text { peritoneal } \\
\text { resident } \\
\text { macrophages }\end{array}$ & $\begin{array}{l}\text { thioglycolate- } \\
\text { induced } \\
\text { macrophages }\end{array}$ & $\begin{array}{l}\text { adherent } \\
\text { spleen cells }\end{array}$ \\
\hline None & $25 \cdot 2(5 \cdot 3)$ & $74 \cdot 3(8 \cdot 2)$ & $51 \cdot 2(4 \cdot 0)$ \\
\hline 7 & $30 \cdot 2(6 \cdot 5)$ & $76 \cdot 8(6 \cdot 3)$ & $56 \cdot 0(2 \cdot 5)$ \\
\hline 3 & $27 \cdot 5(3 \cdot 8)$ & $65 \cdot 2(7 \cdot 8)$ & $56 \cdot 0(3 \cdot 7)$ \\
\hline 1 & $28.9(4 \cdot 0)$ & $60 \cdot 8(5.6)$ & $48 \cdot 2(4 \cdot 2)$ \\
\hline
\end{tabular}

* Cy-A $25 \mathrm{mg} / \mathrm{kg}$ as a single i.p. injection a number of days before the in vitro assay (day 0 ).

$\uparrow$ Ratio of effector : target cells was $10: 1$; data are the means of quadruplicate samples.

table VI, the i.p. or i.m. injection of Cy-A significantly decreased the resistance to $C$. albicans challenge in vivo as well as the candidacidal activity of PMNL in vitro. However, s.c. administration failed to cause any significant effect. These results further indicate the relevance of $\mathrm{Cy}-\mathrm{A}$ inhibition of PMNL activity as a possible mechanism responsible for the depression of resistance in vivo.

Partial reconstitution of PMNL activity in $C y-A$ treated animals by transfer of $T$ lymphocytes

Cy-A selectively inhibits T-cell functions (Borel et al., 1976; Larsson, 1980; Wiesinger and Borel, 1980; Bunjes et al., 1981; Britton and Palacios, 1982; Kauffman et al., 1984). To study further the effect of Cy-A on PMNL activity, we examined the possible effect of T-cell transfer on PMNL activity in Cy-A-treated mice. Animals were treated with Cy-A $50 \mathrm{mg} / \mathrm{kg} 3$ days before the assay; 2 days before the assay, one group of mice was given $2.5 \times$ $10^{7}$ cells of a T-lymphocyte enriched population from normal donors (see Material and methods) by i.v. injection. Both the ${ }^{51} \mathrm{Cr}$-release assay and the cfu-inhibition assay indicated that lymphocyte transfer partly reconstituted the PMNL activity (table VII). These data suggest that the Cy-Ainduced decline of PMNL activity could be due, at least in part, to the effect of $\mathrm{Cy}-\mathrm{A}$ on $\mathrm{T}$ lymphocytes.

Partial reconstitution of PMNL activity in $C y-A$ treated mice by IFN- $\gamma$

It was reported recently that IFN- $\gamma$ increased PMNL-mediated candidacidal activity (Djeu et al., 
Table V. Correlation between in-vitro candidacidal activity of PMNL from normal or Cy-A-treated CD2F1 mice and protective activity against $C$. albicans infection in immunodepressed mice*

\begin{tabular}{|c|c|c|c|c|c|c|}
\hline \multirow[b]{2}{*}{ Group } & \multirow[b]{2}{*}{ Challenge $\dagger$} & \multicolumn{2}{|c|}{$\begin{array}{l}\text { Percentage }{ }^{51} \mathrm{Cr} \text { specific release by } \\
\text { PMNL in vitro at ratio }\end{array}$} & \multicolumn{3}{|c|}{ Results of $C$. albicans challenge } \\
\hline & & $10: 1 \ddagger$ & $2 \cdot 5: 1 \ddagger$ & MST & $\begin{array}{l}\text { Number of mice } \\
\text { dead (10 per } \\
\text { group) }\end{array}$ & $\begin{array}{l}\text { Survival } \\
\text { range (days) }\end{array}$ \\
\hline 1 & $1 \times 10^{4}$ C. albicans cells & $\ldots$ & $\ldots$ & $2 \cdot 5 \S$ & 10 & $2-3$ \\
\hline 2 & $\begin{array}{l}1 \times 10^{4} \text { C. albicans cells after incuba- } \\
\text { tion for } 1 \mathrm{~h} \text { with PMNL from } \\
\text { untreated mice }\end{array}$ & $35 \cdot 2$ & $30 \cdot 5$ & $7 \cdot 0$ & 10 & $6-8$ \\
\hline 3 & $\begin{array}{l}1 \times 10^{4} \text { C. albicans cells after incuba- } \\
\text { tion for } 1 \mathrm{~h} \text { with PMNL from mice } \\
\text { treated with Cy-A } 25 \mathrm{mg} / \mathrm{kg} 3 \text { days } \\
\text { before the assay }\end{array}$ & $18 \cdot 3 \|$ & $14 \cdot 5 \|$ & $2 \cdot 0 \S$ & 10 & $2-3$ \\
\hline 4 & $\begin{array}{l}1 \times 10^{4} \text { C. albicans cells after incuba- } \\
\text { tion for } 1 \mathrm{~h} \text { with PMNL from mice } \\
\text { treated with Cy-A } 25 \mathrm{mg} / \mathrm{kg} 1 \text { day } \\
\text { before the assay }\end{array}$ & $17 \cdot 5 \|$ & $12 \cdot 6 \|$ & $2 \cdot 5 \S$ & 10 & $2-3$ \\
\hline
\end{tabular}

*The same PMNL population was used as an effector in the in-vitro assay and in the in-vivo transfer experiment

†Mice immunodepressed with cyclophosphamide $\left(150 \mathrm{mg} / \mathrm{kg} 3\right.$ days before challenge) were given by i.v. injection $1 \times 10^{4}$ C. albicans cells previously incubated for $1 \mathrm{~h}$ with RPMI medium (group 1), or with PMNL from untreated (group 2) or Cy-A-treated (groups 3 and 4) mice.

$\ddagger$ Ratios of effector: target cells; data are the means of quadruplicate samples; standard errors, usually $<1.5 \%$, have been omitted. $\| \mathrm{p}<0.01$ (groups 3 and 4 versus group 2).

$\S \mathrm{p}<0.01$ (groups 1, 3 and 4 versus group 2).

Table VI. Effect of different routes of Cy-A administration on PMNL candidacidal activity and resistance of $\mathrm{CD} 2 \mathrm{~F} 1$ mice to systemic challenge with C. albicans

\begin{tabular}{|c|c|c|c|c|c|c|c|}
\hline \multicolumn{2}{|c|}{$\begin{array}{l}\text { Treatment with } \mathrm{Cy}-\mathrm{A}^{*} \\
\text { before challenge }\end{array}$} & \multicolumn{3}{|c|}{ C. albicans challenge } & \multicolumn{3}{|c|}{ Percentage ${ }^{51} \mathrm{Cr}$ specific release at ratio } \\
\hline Days & Route & MST & $\begin{array}{c}\text { Number of mice } \\
\text { dead (10 per group) }\end{array}$ & $\begin{array}{l}\text { Survival range } \\
\text { (days) }\end{array}$ & $10: 1 \dagger$ & $5: 1 \dagger$ & $2 \cdot 5: 1 \dagger$ \\
\hline \multicolumn{2}{|c|}{ None } & 8 & 10 & $6-9$ & $33 \cdot 1$ & $29 \cdot 9$ & $20 \cdot 3$ \\
\hline 3 & i.p. & $4 \ddagger$ & 10 & $2-5$ & $17 \cdot 5 \ddagger$ & $15 \cdot 3 \ddagger$ & $12 \cdot 2 \ddagger$ \\
\hline 1 & i.p. & $2 \ddagger$ & 10 & $1-4$ & $10 \cdot 8 \ddagger$ & $9.8 \ddagger$ & $7 \cdot 7 \ddagger$ \\
\hline 3 & s.c. & 9 & 10 & $7-9$ & $32 \cdot 1$ & $23 \cdot 7$ & $20 \cdot 7$ \\
\hline 1 & s.c. & 7 & 10 & $6-10$ & $28 \cdot 0$ & $25 \cdot 6$ & $20 \cdot 5$ \\
\hline 3 & i.m. & $5 \ddagger$ & 10 & $2-5$ & $12 \cdot 1 \ddagger$ & $9.9 \ddagger$ & $8.6 \ddagger$ \\
\hline 1 & i.m. & $4 \ddagger$ & 10 & $1-5$ & $12 \cdot 5 \ddagger$ & $11 \cdot 7 \ddagger$ & $8.9 \ddagger$ \\
\hline
\end{tabular}

${ }^{*} \mathrm{Cy}-\mathrm{A} 25 \mathrm{mg} / \mathrm{kg}$ was given as a single i.p. injection days before challenge with $5 \times 10^{5} \mathrm{C}$. albicans cells $/$ mouse.

$\dagger$ Ratios of effector: target cells; data are the means of quadruplicate samples; standard errors, usually $<1.5 \%$, have been omitted.

$\ddagger \mathrm{p}<0.01$ (Cy-A treated mice versus controls).

1986). To examine further the possible mechanism of Cy-A-induced inhibition of PMNL activity, we measured the effect of IFN- $\gamma$ on the activity, in vitro, of PMNL from $\mathrm{Cy}$-A-treated and normal control mice (fig. 3). The incubation of PMNL with different doses of IFN- $\gamma$ resulted in a significant augmentation of their activity as evaluated by both ${ }^{51} \mathrm{Cr}$-release and cfu-inhibition assay. This potentiating effect was more marked for PMNL from Cy-A-treated animals than for those from normal animals. These data could indicate that lack of IFN- $\gamma$ production in Cy-A-treated mice may ac- 
Table VII. Effect of lymphocyte transfer on candidacidal activity of PMNL from normal or Cy-A-treated mice

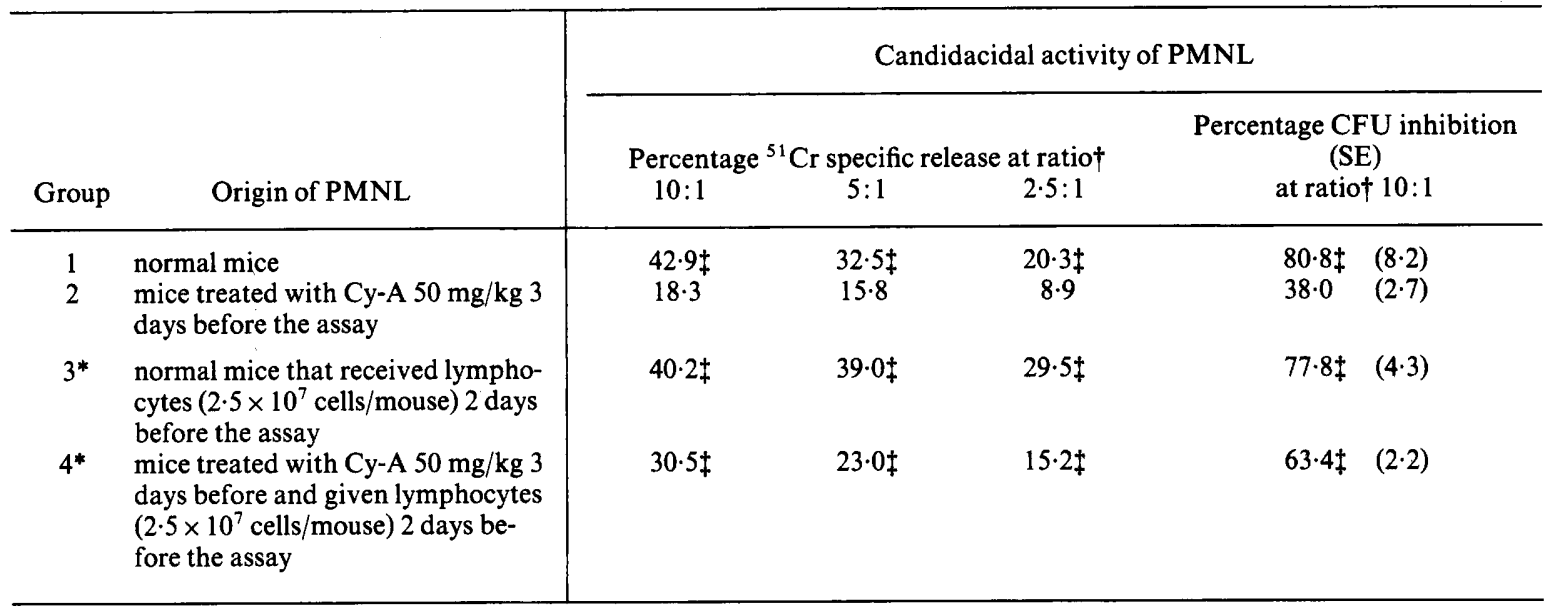

*The transferred lymphocyte population from normal mice was $98 \%$ Thyl + T lymphocytes (see Materials and methods).

$\uparrow$ Ratios of effector: target cells; data are the means of quadruplicate samples. Standard errors of the ${ }^{51} \mathrm{Cr}-\mathrm{release}$ assay, $<15 \%$, have been omitted.

$\ddagger \mathrm{p}<0 \cdot 01$ (groups 1,3 and 4 versus group 2).

count, at least in part, for the decrease of PMNL candidacidal activity.

\section{Discussion}

We have shown that phagocytic cells play an important role in resistance to experimental $C$. albicans infection in vivo (Baccarini et al., 1983a; Bistoni et al., 1986). We also found that modulation of numbers of macrophages and PMNL or their activity, or both, may influence this resistance, suggesting that the phagocytic killing mediated by macrophages and PMNL could play a role. Previous observations indicate that macrophages and PMNL are able to kill C. albicans in vitro as well as inhibit colony formation (Lehrer, 1972). Our observations tend to exclude a direct role for $\mathrm{T}$ cells and natural killer (NK) cells in host resistance against infection as well as in killing or growth inhibition, or both, of $C$. albicans in vitro. Furthermore, anticandida effector cells lack typical markers of either $\mathrm{T}$ or NK cells and their in vivo reactivity shows characteristics which differ from those of NK activity, including age and genetic influences (Baccarini et al., 1983b).

To analyse further the mechanisms that may be involved in resistance to $C$. albicans infection, we manipulated host reactivity by treating animals with $\mathrm{Cy}-\mathrm{A}$. Unlike other agents, $\mathrm{Cy}-\mathrm{A}$ does not attack all lymphocyte populations indiscriminately, but acts only against selected ones. It has been reported that Cy-A selectively depletes $\mathrm{T}$ cells, and, in particular, T-helper and T-cytotoxic cells. More specifically, it acts at an early stage in the life cycle of $\mathrm{T}$ lymphocytes, inhibiting their activation by blocking the intercellular message carried by interleukin-2 (Il-2) (Bunjes et al., 1981; Kaufmann et al., 1984; Hess and Colombani, 1986). It has been proposed that $\mathrm{Cy}$-A spares both myeloid tissue and the non-specific arm of the defence system and that it has no effect on neutrophils or macrophages (Weinbaum et al., 1984; Lun et al., 1985). Although additional actions may yet be defined, the major effect of Cy-A seems to be its ability to inhibit Tcell functions by acting at three distinct but related stages in the process of $\mathrm{T}$-cell activation: (1) inhibiting $T$ cell help of accessory cells for the synthesis of IL-1; (2) preventing IL-2-producing T cells from expressing receptors for IL-1 and suppressing the synthesis of IL-2; (3) rendering T cells unresponsive to IL-2 (Borel et al., 1976; Bunjes et al., 1981; Hess and Colombani, 1986).

The data reported here indicate that $\mathrm{Cy}-\mathrm{A}$ decreases the spontaneous reactivity of PMNL against $C$. albicans as evaluated by in-vivo and invitro experiments. Evidence for this depressive effect on PMNL was a significantly decreased cytotoxic activity in vitro, as shown by the cfu assay and by $\mathrm{a} 4-\mathrm{h}^{51} \mathrm{Cr}$-release assay against radiolabelled C. albicans. Furthermore, PMNL from Cy-A treated mice also showed significantly decreased phagocytic activity in vitro (fig. 2) which could account for the decreased cytotoxic activity observed (table III). This depressed activity was also 

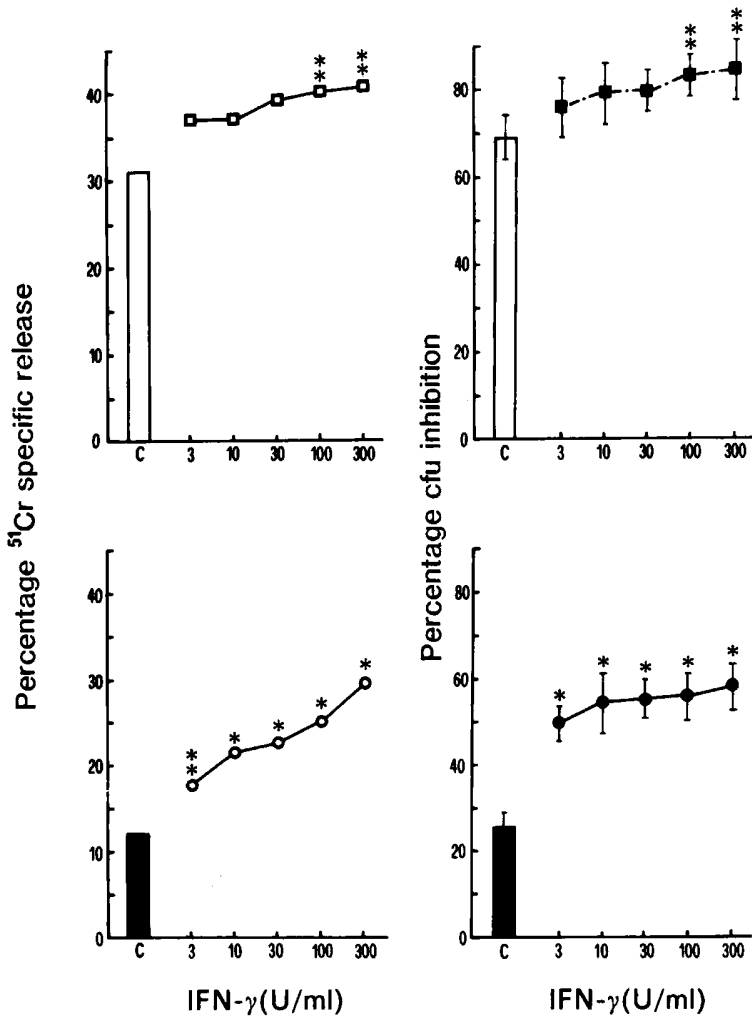

Fig. 3. Candidacidal activity of PMNL from normal or Cy-Atreated $\mathrm{CD} 2 \mathrm{~F} 1$ mice after exposure in vitro to IFN- $\gamma$. PMNL from normal mice $(\square-\square, \square-\square)$ or Cy-A-treated mice (O-O, - ) were exposed to mouse recombinant IFN- $\gamma$ for $2 \mathrm{~h}$ before the assay and during the $4-\mathrm{h}$ incubation period. The ${ }^{51} \mathrm{Cr}$ release assay and cfu-inhibition assay were performed at effector : target ratios of 10:1. Standard errors of the ${ }^{51} \mathrm{Cr}$ release assay, usually $<1.5 \%$, have been omitted. Vertical bars represent the standard errors of the cfu-inhibition assay; ${ }^{*}, \mathrm{p}<0.01 ;{ }_{*}^{*}, \mathrm{p}<0.05$ for IFN- $\gamma$-treated PMNL versus controls.

evident in vivo. Cy-A decreased resistance to $C$. albicans challenge (fig. 1; tables I and VI) and also reduced significantly the protective capability of PMNL transferred from Cy-A-treated mice into immunodepresse mice to a subsequent challenge with C. albicans (table V). The decreased resistance to $C$. albicans challenge in vivo also indicates that Cy-A impairs the activity of PMNL in vivo. However, Cy-A did not affect the viability and candidacidal activity of PMNL when incubated in vitro for different times and with different drug concentrations (data not shown).

Because of previous observations that $\mathrm{T}$ lympho- cytes are the cell population mainly affected by $\mathrm{Cy}$ A treatment (Borel et al., 1976; Larsson, 1980; Wiesinger and Borel, 1980; Bunjes et al., 1981; Britton and Palacios, 1982; Kauffman et al., 1984), we tested the possibility that the depressive effect on PMNL activity was a consequence of the drugmediated effect on $\mathrm{T}$ lymphocytes. We evaluated the effect of treatment with Cy-A $(25 \mathrm{mg} / \mathrm{kg} 1$ or 3 days before assay) on T-cell mediated alloreactivity in vivo or cytotoxic $\mathrm{T}$-lymphocyte generation in vitro, as well as the proliferative response to PHA. Our results showed that the treatments that reduced PMNL candidacidal activity also inhibited these T-cell functions (data not shown).

These observations suggested a possible relationship between the effects of Cy-A on T-cell activity and the effects on PMNL candidacidal activity. Therefore, we performed transfer experiments in an attempt to reconstitute PMNL activity in Cy-Atreated mice. Our results (table VII) show clearly that transfer of nylon non-adherent, T-cell enriched, spleen cells partly reconstituted the PMNL candidacidal activity in vivo.

We also examined the effect of treatment of PMNL from Cy-A-treated mice with IFN- $\gamma$ in vitro. Our data (fig. 3) show that IFN- $\gamma$ treatment partly reconstituted the PMNL candidacidal activity. On the basis of our data and previously reported observations that Cy-A strongly affects IL-2 production by $T$ lymphocytes and that IL- 2 may, in turn, stimulate the production of IFN- $\gamma$, we suggest that $\mathrm{Cy}-\mathrm{A}$-induced depression of PMNL activity could be due, at least in part, to inhibition of T-cell dependent IL-2 and IFN- $\gamma$ production (Farrar $e t$ al., 1986). Moreover, recently IFN- $\gamma$ has been reported to stimulate PMNL-mediated candidacidal activity (Djeu et al., 1986), which suggests a possible physiological role of IFN- $\gamma$ in maintaining levels of PMNL activity necessary for host defence against infections. These proposed mechanisms may account, in part, for the $\mathrm{Cy}$-A-induced decrease of resistance to C. albicans infection, although other cells and factors may also be involved in this phenomenon.

This work was supported by Contract no. 87.00579.52 within the Progetto Finalizzato per il Controllo della Malattie da Infezione from the Consiglio Nazionale delle Ricerche, Italy. We are grateful to Eileen Zannetti for her excellent assistance in the preparation of this manuscript. 


\section{REFERENCES}

Baccarini M, Bistoni F, Puccetti P, Garaci E 1983a Natural cellmediated cytotoxicity against Candida albicans induced by cyclophosphamide: nature of the in vitro cytotoxic effector. Infection and Immunity 42: 1-9.

Baccarini M, Blasi E, Puccetti P, Bistoni F $1983 b$ Phagocytic killing of Candida albicans by different murine effector cells. Sabouraudia 21 : 271-286.

Baccarini M, Vecchiarelli A, Cassone A, Bistoni F 1985 Killing of yeast, germ-tube and mycelial forms of Candida albicans by murine effectors as measured by a radiolabel release microassay. Journal of General Microbiology 131 : 505-513.

Bistoni F, Baccarini M, Blasi E, Marconi P, Puccetti P, Garaci E 1983 Correlation between in-vivo and in-vitro studies of modulation of resistance to experimental Candida albicans infection by cyclophosphamide in mice. Infection and Immunity 40: 46-55.

Bistoni F, Baccarini M, Blasi E, Puccetti P, Marconi P 1982 A radiolabel release microassay for phagocytic killing of Candida albicans. Journal of Immunological Methods 52 : 369-377.

Bistoni F, Vecchiarelli A, Cenci E, Puccetti P, Marconi P, Cassone A 1986 Evidence for macrophage-mediated protection against lethal Candida albicans infection. Infection and Immunity 51 : 668-674.

Bistoni F, Vecchiarelli A, Cenci E, Sbaraglia G, Perito S, Cassone A 1984 A comparison of experimental pathogenicity of Candida species in cyclophosphamide-immunodepressed mice. Sabouraudia 22: 409-418.

Bistoni F, Vecchiarelli A, Mazzolla R, Puccetti P, Marconi P, Garaci E 1985 Immunoadjuvant activity of amphotericin B as displayed in mice infected with Candida albicans. Antimicrobial Agents and Chemotherapy 27: 625-631.

Borel J F, Feurer C, Gubler H U 1976 Biological effects of cyclosporin A: a new antilymphocytic agent. Agents and Actions 4: 468-475.

Bout D, Deslèe D, Capron A 1986 Antischistosomal effect of cyclosporin A: cure and prevention of mouse and rat Schistomiasis mansoni. Infection and Immunity 52: 823-827.

Britton S, Palacios R 1982 Cyclosporin A. Usefulness, risks and mechanism of action. Immunological Reviews 65: 5-22.

Bunjes D, Hardt C, Röllinghoff M, Wagner H 1981 Cyclosporin A mediates immunosuppression of primary cytotoxic $T$ cell responses by impairing the release of interleukin 1 and interleukin 2. European Journal of Immunology 11 : 657-661.

Djeu J Y, Blanchard D K, Halkias D, Friedman H 1986 Growth inhibition of Candida albicans by human polymorphonuclear neutrophils: activation by interferon- $\gamma$ and tumor necrosis factor. Journal of Immunology 137: 2980-2984.

Farrar W L, Birchenall-Sparks M C, Young H B 1986 Interleukin 2 induction of interferon- $\gamma$ mRNA synthesis. Journal of Immunology 137: 3836-3840.

Hess A D, Colombani P M 1986 Cyclosporin mechanism of action: in vitro studies. In: Borel J F (ed) Progress in allergy, vol 38, Ciclosporin. Karger, Basel, pp 198-221.

Hurtrel B, Lagrange P H, Michel J C 1980 Systemic candidiasis in mice. II. Main role of polymorphonuclear leukocytes in resistance to infection. Annales d'Immunologie 131: 105118.

Julius M H, Simpson E, Herzenberg L A 1973 A rapid method for the isolation of functional thymus-derived murine lymphocytes. European Journal of Immunology 3: 645-652.

Kaufmann Y, Chang A E, Robb R J, Rosenberg S A 1984 Mechanism of action of cyclosporin A: inhibition of lymphokine secretion studied with antigen-stimulated $\mathrm{T}$ cell hybridomas. Journal of Immunology 133: 3107-3111.

Klock J C, Bainton D F 1976 Degranulation and abnormal bactericidal functions of granulocytes procured by reversible adhesion to nylon wool. Blood 48: 149-161.

Larsson E L 1980 Cyclosporin A and dexamethasone suppress $T$ cell responses by selectively acting at distinct sites of the triggering process. Journal of Immunology 124: 2828-2833.

Lehrer R I 1969 Antifungal effects of peroxidase systems. Journal of Bacteriology 99 : 361-365.

Lehrer R I 1972 The fungicidal activity of human leukocytes. In: Williams $\mathrm{R} \mathrm{C}$, Fudenberg $\mathrm{H} \mathrm{H}$ (eds) Phagocytic mechanisms in health and disease. Thieme, Stuttgart, pp 151-166.

Lun M T et al. 1985 Monocytes phagocytic activity in cyclosporine treated patients. Microbiologica 8: 277-282.

Marconi P, Bistoni F, Boncio L, Bersiani A, Bravi P, Pitzurra M 1976 Utilizzazione di soluzione saline ipertonica di cloruro di potassio $(3 \mathrm{M} \mathrm{KCl})$ per l'estrazione di antigeni solubili da Candida albicans. Annali Sclavo 18: 61-66.

Mattia E, Carruba G, Angiolella L, Cassone A 1982 Induction of germ tube formation by $\mathrm{N}$-acetyl-D-glucosamine in Candida albicans: uptake of inducer and germinative response. Journal of Bacteriology 152: 555-562.

Moser S A, Domer J E 1980 Effects of cyclophosphamide on murine candidiasis. Infection and Immunity $27: 376-386$.

Ruthe R C, Andersen B R, Cunningham B L, Epstein R B 1978 Efficacy of granulocyte transfusions in the control of systemic candidiasis in the leukopenic host. Blood 52: 493498.

Sasada M, Johnston R B 1980 Macrophage microbial activity. Correlation between phagocytosis-associated oxidative metabolism and the killing of Candida by macrophages. Journal of Experimental Medicine 152: 85-98.

Shalaby M R, Aggarwal B B, Rinderknecht E, Svedersky L P, Finkle B S, Palladino M A 1985 Activation of human polymorphonuclear neutrophil functions by interferon- $\gamma$ and tumor necrosis factors. The Journal of Immunology 135 : 2069-2073.

Weinbaum D L, Kaplan S S, Zdziarski U, Rinaldo C R, Schroeder K K 1984 Human polymorphonuclear leukocyte interaction with Cyclosporine A. Infection and Immunity 43 : 791-794.

Wiesinger D, Borel J F 1980 Studies on the mechanism of action of cyclosporin A. Immunobiology 156: 454-463. 